Research Paper

\title{
Yeast biomass production: a new approach in glucose-limited feeding strategy
}

\author{
Érika Durão Vieira ${ }^{1}$, Maria da Graça Stupiello Andrietta ${ }^{2}$, Silvio Roberto Andrietta ${ }^{2}$ \\ ${ }^{1}$ Faculdade de Engenharia Química, Universidade Estadual de Campinas, Campinas, SP, Brazil. \\ ${ }^{2}$ Centro Pluridisciplinar de Pesquisas Químicas, Biológicas e Agrícolas, \\ Universidade Estadual de Campinas, Paulínia, SP, Brazil.
}

Submitted: June 27, 2011; Approved: September 10, 2012.

\begin{abstract}
The aim of this work was to implement experimentally a simple glucose-limited feeding strategy for yeast biomass production in a bubble column reactor based on a spreadsheet simulator suitable for industrial application. In biomass production process using Saccharomyces cerevisiae strains, one of the constraints is the strong tendency of these species to metabolize sugars anaerobically due to catabolite repression, leading to low values of biomass yield on substrate. The usual strategy to control this metabolic tendency is the use of a fed-batch process in which where the sugar source is fed incrementally and total sugar concentration in broth is maintained below a determined value. The simulator presented in this work was developed to control molasses feeding on the basis of a simple theoretical model in which has taken into account the nutritional growth needs of yeast cell and two input data: the theoretical specific growth rate and initial cell biomass. In experimental assay, a commercial baker's yeast strain and molasses as sugar source were used. Experimental results showed an overall biomass yield on substrate of 0.33 , a biomass increase of 6.4 fold and a specific growth rate of $0.165 \mathrm{~h}^{-1}$ in contrast to the predicted value of $0.180 \mathrm{~h}-1$ in the second stage simulation.
\end{abstract}

Key words: yeast, biomass, fed-batch, process simulation, Saccharomyces cerevisiae.

\section{Introduction}

Microbial biomass is a suitable supplemental protein source obtained from processes in which bacteria, yeasts, other fungi or algae are cultivated in large quantities. Yeast biomass is extensively used as human or animal protein supplement in animal feed or in human nutrition (Halasz and Lasztity, 1991). Common strains used as single cell protein source includes Saccharomyces cerevisiae and Candida utilis strains. Typical microbial biomass products include bakers' yeast and yeast extracts where Saccharomyces cerevisiae strains are the host for heterologous-protein production (Beudeker et al., 1990; Hensing et al., 1995).

Basically, the industrial process concept relies on propagating cells from pure culture agar slants to large bioreactors increasing volume in each propagation stage till the final bioreactor volume (Rose, 1979; Burrows, 1979; EPA, 1995; Rendez-Gil, Sanz and Priteo, 1999; Di Serio et al., 2001; Di Serio, Tesser and Santacesaria, 2001). How- ever, besides this simple concept, industrial production aims at efficient conversion of sugar feedstock into yeast biomass mainly in the later stages where biomass volume is high. An efficient transformation of sugar in yeast protein requires that anaerobic metabolites production such as ethanol and acetaldehyde (Bauer et al., 1999) is minimized, i.e., that sugar metabolism is deviated to the oxidative pathway to achieving maximum ATP energy yield and biomass formation (Van Hoek, Van Dijken and Pronk, 1998). Moreover, fermentation products such as ethanol and, in particular, acetaldehyde are toxic. This problem becomes especially relevant during cultivation at high biomass densities (Hensing et al., 1995; van Dijken, Weusthuis and Pronk, 1993).

It's generally known that Saccharomyces cerevisiae species tends to metabolize glucose glycolytically under glucose excess even in fully aerobic conditions producing ethanol, a phenomenon known as the Crabtree effect (Käppeli, 1986; Sonnleitner and Käppeli, 1986; Verduyn, 
1991; Dynesen, 1998). Additionally, not only glucose but also fructose has shown to triggers catabolite repression on Saccharomyces cerevisiae strains (Dynesen, 1998). This catabolite repression renders low biomass yield when cultivating Saccharomyces cerevisiae in batch cultures and negatively affects biomass yields due to the low ATP yield from alcoholic fermentation. Despite this, biomass formation can be achieved by innumerous metabolic pathways (Frick and Whitmann, 2005) and biomass yield on substrate can reach values up to $50 \%$ in pure oxidative growth (Akinyemi, Betiku and Solomon, 2005).

To overcome these constraints on yeast biomass production two important variables are of major importance: oxygen transfer rate and glucose concentration in the broth. In heterogeneous gas-liquid reactions, e.g., in aerobic fermentation, the liquid phase controls mass transfer processes due to the relative insolubility of gases. This limitation is minimized by the use of bubble column reactors due to its good oxygen transfer with low cost operation when compared to stirred tank reactors (Kantarcia, Borakb and Ulgen, 2005). The minimum sugar concentration in broth can be reached by the use of a fed-batch process. This process concept is the current one in industrial scale and renders good biomass yields when appropriate process control strategy is used. Traditionally, in industrial production, molasses or another feedstock feeding follows a strategy built on the basis of factory historic data and so it is peculiar to a determined strain and other process conditions. Nowadays, not only for economic reasons but also because of environmental policy, some industries are investing in new strategies of process control to avoid emission of toxic pollutants (EPA, 1995). In scientific literature, many articles can be found about baker's yeast production dealing with yeast growth modeling and aiming at different goals such as productivity, yield and yeast quality as well as new and robust online sensors (Reyman, 1992; Rigbom, Rothberg and Saxen, 1996; Rendez-Gil, Sanz and Priteo, 1999; Jones and Kompala, 1999; Di Serio et al., 2001; DiSerio, Tesser and Santacesaria, 2001; Soley, 2005). However, there are few simple theoretical models for yeast biomass production that could fit to any strain and process and could be applicable to industrial scale.

The objective of the present work was, therefore, to develop and implement experimentally a simple theoretical model for yeast growth based on few parameters aiming at achieving a glucose-limited feeding strategy applicable to industrial scale. For this purpose, a spreadsheet was developed in which the theoretical model could predict at each time interval the nutritional growth needs of yeast cell based on two major input data: the theoretical specific growth rate and initial cell biomass. The model was validated in a laboratory scale experiment. Biomass production was performed in a 5-liter bubble column reactor using a commercial baker's yeast strain. The first two stages of yeast cell propagation, common in industrial process, were simulated experimentally using sugar cane molasses as carbon source.

\section{Materials and Methods}

\section{Operational system}

The operational system is shown in Figure 1. The reactor design used in this work was a cylindrical acrylic vessel of 5.5 liter volume with a conic bottom. At the end of the conic bottom it was connected a $1 \mathrm{~cm}$ tube for air entrance without any kind of air distributor. Five equally spaced transversal 4-hole baffles were added to the design to create turbulence and shear which could break up the air bubbles. The design also included small outlet tubes from were molasses could be fed and cells could be circulated out through a glass coil heat exchanger connected to a $34{ }^{\circ} \mathrm{C}$ thermostatic bath. Aeration was estimated by scale down of typical industrial conditions: $0.3 \mathrm{vvm}$ for the first stage and $1.3 \mathrm{vvm}$ for the second stage. The scale down was based on the criterion of geometric similarity of the reactors and identical mass transfer coefficient $\left(\mathrm{k}_{\mathrm{La}}=\mathrm{k}_{\mathrm{La} 2}\right.$ ) (Aiba, 1971). It resulted in $2.5 \mathrm{vvm}(9 \mathrm{lpm})$ for first stage and $1.3 \mathrm{vvm}$ (approximately $30 \mathrm{lpm}$ ) for the second stage. The reactor was washed previously with $5 \%$ sodium hydroxide solution to prevent excessive bacterial contamination.

\section{Microorganism}

The microorganism evaluated in this assay was a commercial baker'yeast strain of Saccharomyces cerevisiae named Y167 from CPQBA yeast collection. This strain was chosen due to its known characteristic of possessing a high cell growth rate. The microorganism was preserved in potato-dextrose agar (PDA) submerged in mineral oil and stored at $4{ }^{\circ} \mathrm{C}$. The propagation was initiated by transferring the preserved microorganism to a fresh PDA slant that was incubated at $32^{\circ} \mathrm{C}$ for $24 \mathrm{~h}$.

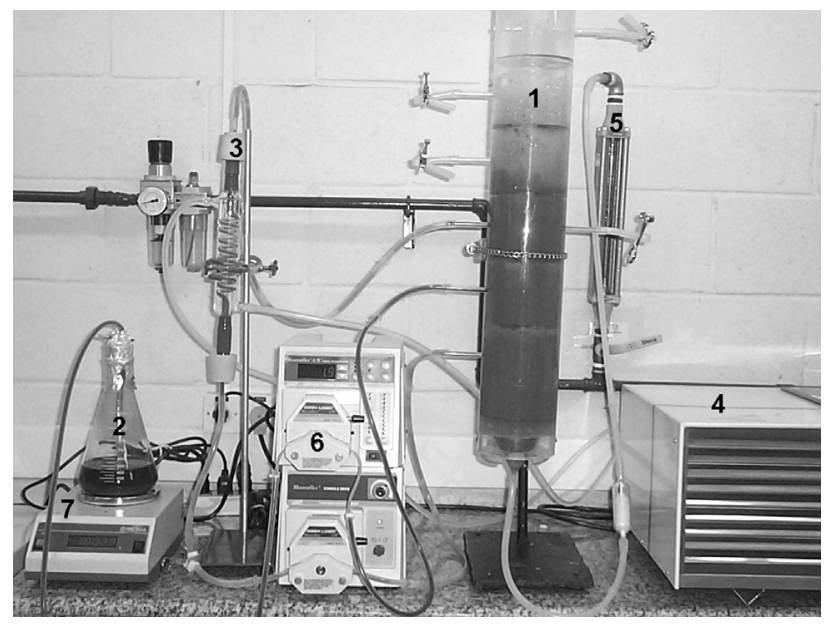

Figure 1 - Operational system: (1) acrylic vessel, (2) molasses flask, (3) glass coil heat exchange, (4) thermostatic bath, (5) rotameter, (6) Masterflex peristaltic pumps and (7) two digits balance. 


\section{Inoculum}

The inoculum used was prepared in $250 \mathrm{~mL}$ Erlenmayer flasks with $100 \mathrm{~mL}$ of sterilized medium (15 min $121^{\circ} \mathrm{C}$ ) composed of : $150 \mathrm{~g} / \mathrm{L}$ sucrose, $6 \mathrm{~g} / \mathrm{L}$ yeast extract, $5 \mathrm{~g} / \mathrm{L}$ potassium phosphate monobasic, $5 \mathrm{~g} / \mathrm{L}$ ammonium chloride, $1 \mathrm{~g} / \mathrm{L}$ magnesium sulphate and $1 \mathrm{~g} / \mathrm{L}$ potassium chloride. The yeast grown in PDA slant for $24 \mathrm{~h}$ at $32{ }^{\circ} \mathrm{C}$ was resuspended in sterilized water and inoculated at a $10 \%$ concentration of total volume of the fermentation medium. The flasks were incubated in a shaker for $24 \mathrm{~h}$ at $32{ }^{\circ} \mathrm{C}$ and $150 \mathrm{rpm}$.

\section{Feed Substratum}

The carbon source used in all assays came from one sole batch of sugar cane molasses from a Brazilian Sugar Mill. This molasses sample was an $80^{\circ}$ Brix with total sugar around $56 \%$ and was diluted conveniently with distillated water to be used in the assays. Potassium phosphate monobasic $\left(\mathrm{KH}_{2} \mathrm{PO}_{4}\right)$ was used as phosphorus source and ammonium chloride $\left(\mathrm{NH}_{4} \mathrm{Cl}\right)$ as nitrogen source. Other vitamins and nutrients are already present in sufficient amounts in the sugar cane molasses so that the fermentation broth was only enriched with those cited salts to guarantee nitrogen and phosphorus supply.

\section{First stage of cell growth}

The reactor was filled with 3.5 liters of diluted sugar cane molasses with approximately $15^{\circ}$ Brix previously sterilized for $10 \mathrm{~min}$ at $121{ }^{\circ} \mathrm{C}$. Molasses was enriched with $\mathrm{KH}_{2} \mathrm{PO}_{4}$ and $\mathrm{NH}_{4} \mathrm{Cl}$ and had the $\mathrm{pH}$ adjusted to 4.5 , the optimum $\mathrm{pH}$ for most Saccharomyces cerevisiae strains (Rose, 1987). The necessary quantity of raw molasses and nitrogen and phosphorus salts were calculated based on the spreadsheet simulator. An amount of $45 \mathrm{~mL}$ of the yeast grown in the flask was incubated in the reactor. This first stage of cell growth was carried out for 16 hour with an aeration level of $9 \mathrm{lpm}$. This stage was carried out without periodical sampling and with carbon source in excess once the goal of this stage is to obtain a maximum increase in biomass in detriment to a loss in biomass on substrate yield (estimated in 0.22 ) and a high productivity. After the 16 hours, the reactor was emptied and rinsed with water and part of the fermentation broth of the first stage was used as inoculum to the second stage. In a industrial process, there is a gradual increment in bioreactors volume so that the volume of the first stage bioreactor is designed to be around $15-20 \%$ of the second stage bioreactor volume and all fermentation broth of the first stage is transferred to the second stage bioreactor to continue the yeast biomass propagation. Due to the absence of a larger bioreactor in laboratory, the second stage assay was carried out in the same acrylic vessel of the first stage and an amount of fermentation broth from the first stage, correspondent to $16 \%$ of final working volume (3.5 liter), was used as inoculum for the second stage.

\section{Second stage of cell growth}

The cleaned reactor was filled with 2 liters of distilled water. This amount was calculated based on the spreadsheet data to complete the final working volume of 3.5 liters. This operation of water addition is usual in industrial yeast biomass production in order to minimize the ethanol concentration produced in the first stage propagation which could inhibit cell growth in the next stage. Subsequently, the reactor was inoculated with $560 \mathrm{~mL}$ ( $16 \%$ of 3.5 liters) of the fermentation broth from the first stage which had its $\mathrm{pH}$ previously adjusted to 4.5 with $\mathrm{HCl} 2 \mathrm{~N}$. The second stage of cell growth was carried out for 12 hours with an aeration level of $30 \mathrm{lpm}$. Diluted molasses $\left(40^{\circ} \mathrm{Brix}\right)$ previously sterilized for $10 \mathrm{~min}$ at $121^{\circ} \mathrm{C}$ was fed incrementally by a peristaltic pump. The feeding rate was controlled by weighting the molasses flask on a two digits balance. At each hour, a specific aliquot of $10 \%(\mathrm{wt} / \mathrm{wt})$ potassium phosphate monobasic solution and $10 \%(\mathrm{wt} / \mathrm{wt}$ ) ammonium chloride solution was added to the fermentation broth. The molasses mass and nitrogen and phosphorus solutions aliquots fed in each time interval were calculated based on the biomass production spreadsheet simulator.

\section{Bioreactor sampling}

In the first stage, two $10 \mathrm{~mL}$ samples were collected at the $0 \mathrm{~h}$ and at the $16 \mathrm{~h}$ and, in the second stage, a $10 \mathrm{~mL}$ sample was collected at each hour to measure biomass (standard method for dry cell mass) and fructose, glucose and sucrose analyses (HPLC). The $10 \mathrm{~mL}$ sample was centrifuged at $4000 \mathrm{rpm}$ and $4 \mathrm{~min}$ in graduated centrifuge tubes. The supernatant was diluted for HPLC analysis in a Dionex chromatography system with a CarboPac PA1 column and pulsed amperometric detection. The wet cell volume was used to estimate cell concentration in the broth considering that dry cell mass $(\mathrm{g})$ is approximately equal to $25 \%$ of wet cell volume $(\mathrm{mL})$. Centrifuged cells were washed with distilled water and centrifuged two times after being transferred to pre-weighed dishes. Cells were dried at $60 \pm 5{ }^{\circ} \mathrm{C}$ to a constant weight.

\section{Biomass production spreadsheet simulator}

A spreadsheet was developed to simulate yeast cell growth and predict its nutritional needs in a fed-batch process under limited-glucose concentration. Cell growth pattern was set as exponential following the general equation $\mathrm{X}=\mathrm{X}_{0} \operatorname{EXP}\left(\mathrm{v}_{0} . \mathrm{t}\right)$, where $\mathrm{X}$ denotes microbial biomass at time $t, X_{0}$ microbial biomass at time $t=0, t$ time in hours $(h)$ and $\mathrm{v}_{0}$ the specific growth rate $\left(\mathrm{h}^{-1}\right)$. Biomass increase at each hour interval could be calculated once inputted the initial cell mass $\left(\mathrm{X}_{0}\right)$ an \pm te $(\bar{\mu})$. The nutritional needs (carbon, nitrogen and phosphorus source) were calculated based on (i) cell average composition of the elements $(\% \mathrm{w} / \mathrm{w})$ carbon, nitrogen and phosphorus (Atkinson and Mavituna, 1991; Lange and Heijnem, 2001) and (ii) yeast cell mass in the reactor at each time $(\mathrm{X}(\mathrm{t}))$. It was considered that only 
Table 1 - Backbone of the spreadsheet simulator.

\begin{tabular}{llccl}
\hline Column & Variable & Symbol & Unit & Formula \\
\hline 1 & time & $\mathrm{t}$ & $\mathrm{h}$ & - \\
2 & Cell Mass at time $t$ & $\mathrm{X}(\mathrm{t})$ & $\mathrm{g}$ & $=\mathrm{X}_{0} * \exp (\bar{\mu} * \mathrm{t})$ \\
3 & Carbon Mass in Cells at time $t$ & $\mathrm{C}(\mathrm{t})$ & $\mathrm{g}$ & $=\mathrm{CF} * \mathrm{X}(\mathrm{t})$ \\
4 & Nitrogen Mass in Cells at time $t$ & $\mathrm{~N}(\mathrm{t})$ & $\mathrm{g}$ & $=\mathrm{NF} * \mathrm{X}(\mathrm{t})$ \\
5 & Phosphorus Mass in Cells at time $t$ & $\mathrm{P}(\mathrm{t})$ & $\mathrm{g}$ & $=\mathrm{PF} * \mathrm{X}(\mathrm{t})$ \\
6 & Carbon Needs & $\Delta \mathrm{C}(\mathrm{t})$ & $\mathrm{g}$ & $=\mathrm{C}(\mathrm{t}+1)-\mathrm{C}(\mathrm{t})$ \\
7 & Total Reducing Sugar Needs & $\Delta \mathrm{TRS}(\mathrm{t})$ & $\mathrm{g}$ & $=\Delta \mathrm{C}(\mathrm{t}) /\left(\mathrm{H} * \mathrm{Y}_{\mathrm{X} / \mathrm{s}}\right)$ \\
8 & Diluted Molasses Needs & $\Delta \mathrm{M}(\mathrm{t})$ & $\mathrm{g}$ & $=\Delta \mathrm{TRS}(\mathrm{t}) * \mathrm{~d} / \mathrm{MP}$ \\
9 & Nitrogen Needs & $\Delta \mathrm{N}(\mathrm{t})$ & $\mathrm{g}$ & $=\mathrm{N}(\mathrm{t}+1)-\mathrm{N}(\mathrm{t})$ \\
10 & $10 \% \mathrm{NH}_{4} \mathrm{CL}$ solution aliquot & $\Delta \mathrm{NS}(\mathrm{t})$ & $\mathrm{mL}$ & $=\Delta \mathrm{N}(\mathrm{t}) * \mathrm{~W} / \mathrm{NFS}$ \\
11 & Phosphorus Needs & $\Delta \mathrm{P}(\mathrm{t})$ & $\mathrm{g}$ & $=\mathrm{P}(\mathrm{t}+1)-\mathrm{P}(\mathrm{t})$ \\
12 & $10 \% \mathrm{KH}_{2} \mathrm{PO}_{4}$ solution aliquot & $\Delta \mathrm{PS}(\mathrm{t})$ & $\mathrm{mL}$ & $=\Delta \mathrm{P}(\mathrm{t}) * \mathrm{~W} / \mathrm{PFS}$ \\
\hline
\end{tabular}

$50 \%$ of the carbon consumed was transformed in biomass, i.e., biomass yield on substrate $\left(\mathrm{Y}_{\mathrm{X} / \mathrm{S}}\right)$ equal to 0.5 . Table 1 shows the spreadsheet backbone implemented in Microsoft Excel Software. Table 2 shows the definitions of the variables used in the spreadsheet simulator.

\section{Results}

The calculated spreadsheet used to estimate the necessary amount of nutrients in the first stage assay is shown in Table 3 . The needed quantity of raw molasses and nitrogen and phosphorus salts were estimated considering a $70 \mathrm{~g}$ biomass content in the reactor at the end of the first stage. This consideration was made on the basis of a estimative of biomass increase of 100 -fold, from $0.7 \mathrm{~g}$ to $70 \mathrm{~g}$ of total biomass, not considering the exponential growth model. The calculated spreadsheet used in the second stage assay is shown in Table 4. It was adopt a specific growth rate of $0.18 \mathrm{~h}^{-1}$ and an expected initial cell mass of $7.0 \mathrm{~g}$ estimated by centrifuged wet cell volume of the inoculum. The molasses purity was $56 \%$ as determined by sugar HPCL (fructose, glucose and sucrose) and Brix analysis. The distillated water volume added in the reactor was calculated by deducting the nutrient volume to be added until the end of the $12 \mathrm{~h}$ and the inoculum volume from the total operational volume of the reactor. Diluted molasses density was considered to be $1.06 \mathrm{~g} / \mathrm{mL}$. It is worth to mention that final volume in the second stage did not reach the expected $3.5 \mathrm{~L}$
Table 2 - Definition of the variables.

\begin{tabular}{|c|c|c|c|}
\hline Variable & Value & Definition & Unit \\
\hline $\mathrm{X}_{0}$ & To be set & Initial cell mass & g \\
\hline $\bar{\mu}$ & To be set & Specific growth rate & $\mathrm{h}^{-1}$ \\
\hline $\mathrm{FC}$ & 0.47 & Carbon weight fraction in yeast cell & - \\
\hline $\mathrm{NF}$ & 0.085 & $\begin{array}{l}\text { Nitrogen weight fraction in yeast } \\
\text { cell }\end{array}$ & - \\
\hline $\mathrm{PF}$ & 0.0113 & $\begin{array}{l}\text { Phosphorus weight fraction in yeast } \\
\text { cell }\end{array}$ & - \\
\hline $\mathrm{H}$ & 0.4 & $\begin{array}{l}\text { Carbon weight fraction of hexose } \\
\text { sugars }\end{array}$ & - \\
\hline $\mathrm{Y}_{\mathrm{X} / \mathrm{S}}$ & 0.5 & Biomass yield on substrate & - \\
\hline $\mathrm{d}$ & To be set & Molasses dilution factor & - \\
\hline MP & To be set & $\begin{array}{l}\text { Molasses sugar purity (TRS per Mo- } \\
\text { lasses, } \mathrm{g} / \mathrm{g} \text { ) }\end{array}$ & $\mathrm{wt} / \mathrm{wt}$ \\
\hline NFS & 0.26 & Nitrogen weight fraction in $\mathrm{NH}_{4} \mathrm{Cl}$ & - \\
\hline PFS & 0.23 & $\begin{array}{l}\text { Phosphorus weight fraction in } \\
\mathrm{KH}_{2} \mathrm{PO}_{4}\end{array}$ & - \\
\hline $\mathrm{W}$ & 10 & Salt concentration & $\% w t / w t$ \\
\hline
\end{tabular}

because of the loss of water stripped by aeration. The final volume was approximately 3 liters and all the concentration data was corrected based on this effect.

The compiled data of the first stage and second stage of cell growth assays are shown in Table 5. In the first stage, biomass yield reached 0.20 as expected in an environment

Table 3 - First stage spreadsheet data built with the following input variables: $\mathrm{X}_{0}=0.7 \mathrm{~g} / \mathrm{L}, \mathrm{Y}_{\mathrm{X} / \mathrm{S}}=0.22, \mathrm{MP}=0.56$ and $\mathrm{d}=1$.

\begin{tabular}{|c|c|c|c|c|c|c|c|c|c|c|c|}
\hline 1 & 2 & 3 & 4 & 5 & 6 & 7 & 8 & 9 & 10 & 11 & 12 \\
\hline $\mathrm{t}$ & $X(t)$ & $C(t)$ & $\mathrm{N}(\mathrm{t})$ & $P(t)$ & $\Delta \mathrm{C}(\mathrm{t})$ & $\Delta \mathrm{TRS}(\mathrm{t})$ & $\Delta \mathrm{M}(\mathrm{t})$ & $\Delta \mathrm{N}$ & $\Delta \mathrm{NS}$ & $\Delta \mathrm{P}$ & $\Delta \mathrm{PS}$ \\
\hline (h) & (g) & (g) & (g) & (g) & (g) & (g) & (g) & (g) & (g) & (g) & (g) \\
\hline 0 & 0.70 & 0.33 & 0.06 & 0.01 & 32.57 & 370.1 & 660.9 & 5.89 & 22.49 & 0.78 & 3.44 \\
\hline 16 & 70.0 & 32.90 & 5.95 & 0.79 & - & - & - & - & - & - & - \\
\hline
\end{tabular}


Table 4 - Second stage spreadsheet data built with the following input variables: $\mathrm{X}_{0}=7.0 \mathrm{~g} / \mathrm{L}, \bar{\mu}=0.18 \mathrm{~h}^{-1}, \mathrm{MP}=0.56$ and $\mathrm{d}=2$.

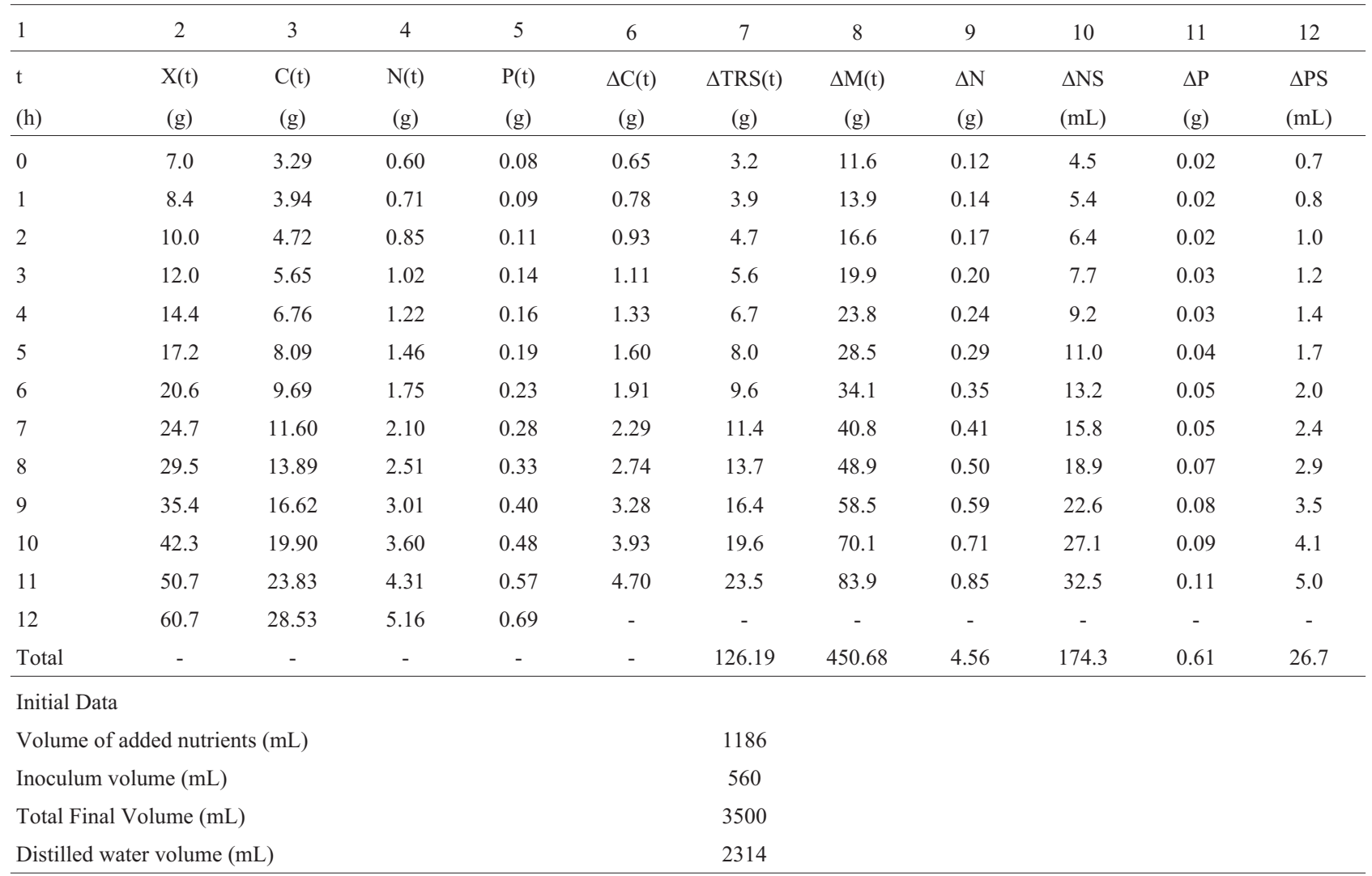

with excess of glucose where anaerobic respiration is preferred by Saccharomyces cerevisiae strains. Biomass increase reached 112.8 fold so that the goal of having a high biomass increase on this first stage was fulfilled. In contrast, in the second stage, the overall biomass yield was higher reaching 0.33 and biomass increase was 6.4 fold, both acceptable values in industrial biomass production. Biomass yield, however, was expected to be closer to 0.5 as it occurs in industrial bioreactors.

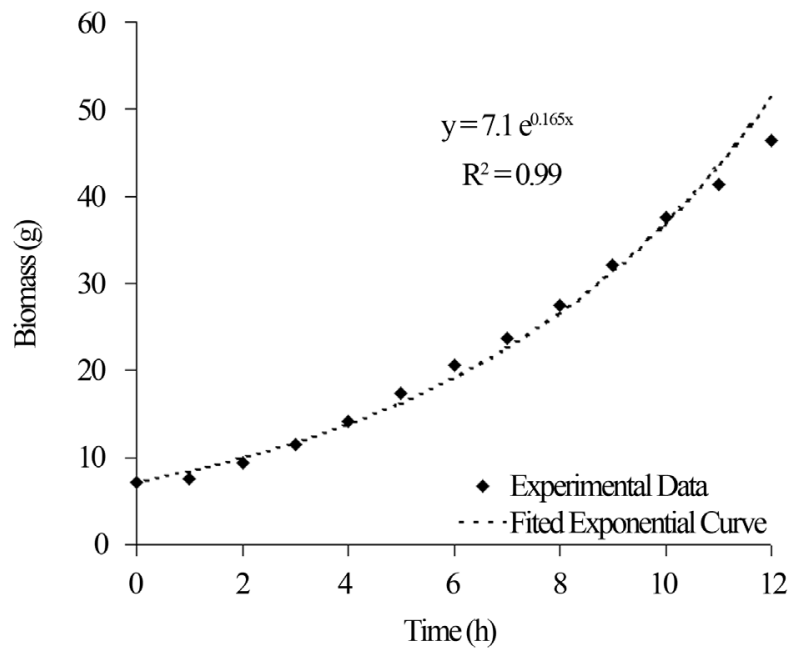

Figure 2 - Cell growth profile.
The cell growth pattern of the second stage is shown in Figure 2. Exponential regression curve fitted well within the experimental data. The specific growth rate was $0.165 \mathrm{~h}^{-1}$ what confirms the Y167 strain good growth parameters and a good initial estimative of $0.18 \mathrm{~h}^{-1}$.

Figure 3 shows the biomass concentration profile. Calculated biomass concentration refers to the values calculated based on the spreadsheet and experimental biomass concentration refers to the values calculated based on the

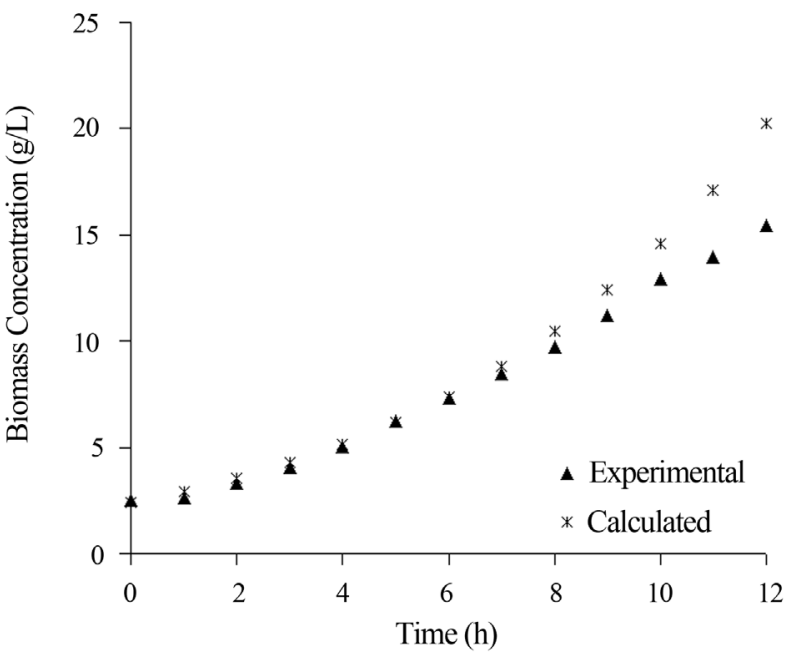

Figure 3 - Biomass concentration profile. 
dry cell mass. These data shows that, after the $6^{\text {th }}$ hour, the real biomass concentration in the reactor was below the expected value and nutrients and sugar may have been fed in excess.

The sugar profile of the second stage is shown in Figure 4. TRS concentration was maintained below $1 \mathrm{~g} / \mathrm{L}$ until the $5^{\text {th }}$ hour. After the 6th hour, TRS increased from approximately $1 \mathrm{~g} / \mathrm{L}$ to $3 \mathrm{~g} / \mathrm{L}$ probably due to the biomass concentration below the predicted value.

Other interesting variables that should help the data analysis are presented in Figure 5. The biomass yield was calculated as instantaneous and cumulative, i.e., the yield in one hour interval $\left(\mathrm{Y}_{\mathrm{X} / \mathrm{S} \text { Instantaneous }}\right.$ in the $5^{\text {th }}$ hour is related to the interval from the $4^{\text {th }}$ hour till the $5^{\text {th }}$ hour) and the yield from the zero time till the current time respectively. The cumulative biomass yield starts at a low value of 0.24 reaching a maximum value of 0.45 at the $6^{\text {th }}$ hour. After the $6^{\text {th }}$ hour, it can be perceived a slightly tendency of lower values

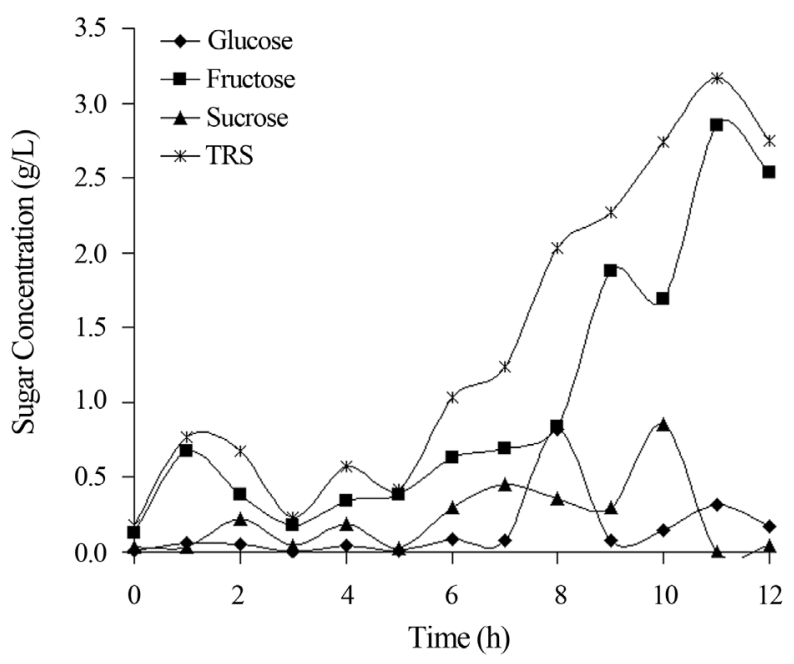

Figure 4 - Sugar profile.

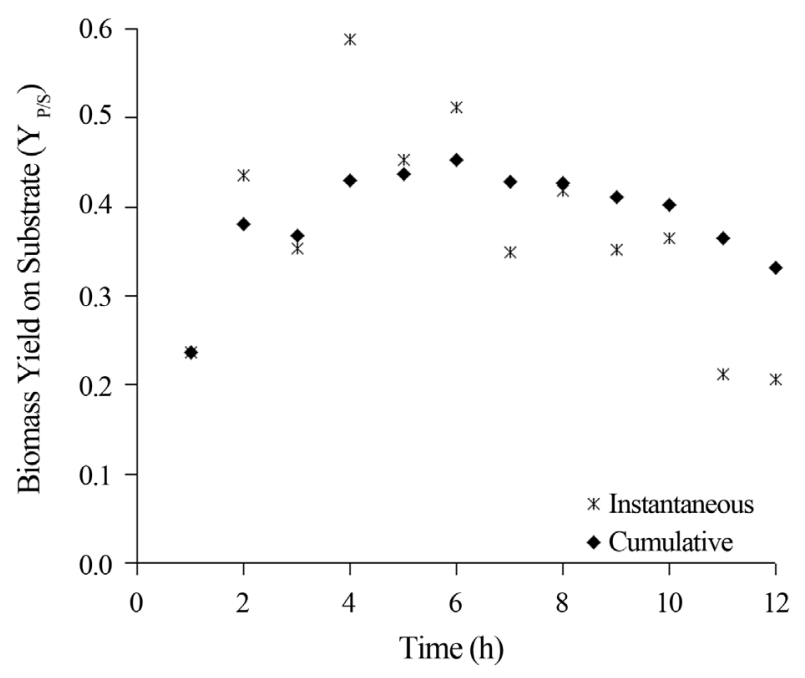

Figure 5 - Instantaneous and cumulative biomass yield profile. till the overall value of 0.33 . In contrast with sugar profile, the cumulative biomass yield drop is closely associated to the TRS increase confirming the strong tendency of yeasts to shift metabolism from aerobic to anaerobic respiration when there is excess of sugar in the broth. Instantaneous biomass yield showed scattered values but it followed the same tendency of the cumulative values.

\section{Discussion}

In typical biomass production plant, yeast propagation starts just like the assay presented in this work: from an agar slant to a seed reactor until a 150.000 liters bioreactors (bubble column reactors). The yeast growth in the flask represents the yeast growth in the seed reactor where a sterile growth is necessary to guarantee a pure culture inoculum. The first stage and second stage in the bubble column reactor represents the first and second stages of yeast propagation on large bioreactors. In the first stage, the objective is to obtain a high increase in biomass (productivity) so that biomass yield on substrate is not an important variable and there is no need to have a feeding control. In the second stage, the objective is to maximize biomass yield on substrate by feeding molasses incrementally in order to avoid catabolite repression. This feeding strategy is used from the second propagation stage until the final bioreactors where biomass yield is of major importance on production costs. The high cell density and high operation volume reached in these stages of the process turn molasses consumption a significant cost variable so that a good feeding strategy and process control is necessary.

Another important variable in biomass production is the aeration and oxygen transfer once biomass yield depends on achieving a fully aerobic condition. This is not an easy condition to be simulated in bubble reactors in laboratorial scale due to the small reactor height that leads to a short residence time of the air bubbles. In the case of the assay presented in this work, the bioreactor operational height was too small compared to industrial bioreactors so that air bubbles residence time was insufficient to achieve maximum dissolved oxygen in broth. The biomass yield values showed on Figure 5 evidences that the experimental conditions did not reach fully aerobic conditions. Therefore, the relatively low biomass yield value obtained in this work is attributed to a limited oxygen availability caused by a poor oxygen transfer and a low residence time of the air bubbles provided by the reactor design and size respectively (Fiecher, Käppeli and Meussdoerffer, 1987). Another fact that supports evidences of the poor oxygenation of the broth was the intense acetaldehyde odor in the laboratory during the assay and the presence and continuously growing concentration of byproducts as detected by the HPLC analysis (results not quantitatively computed).

Cell concentration in the broth after the $6^{\text {th }}$ hour was lower than the calculated value. This suggests that, from the spreadsheet theory, the TRS quantity that was fed from this 
time till the end of the experiment was in excess. This can explain the TRS increase in the broth (Figure 4) and the decrease in biomass yield values (Figure 5) together with poor oxygenation. In higher cell densities conditions, oxygen uptake can be theoretically calculated and added to the spreadsheet so that aeration is increased as biomass increases. The oxygenation bottleneck in small scale operations turns the simulation of the preceding stages difficult. It was simulated de $3^{\text {rd }}$ stage (results not shown herein) but the results showed clearly that oxygen transfer was deficient even when aeration was above $45 \mathrm{lpm}$. Besides it was observed that cells were seriously damaged and cell viability drops to $50 \%$. This was attributed to the strong shear stress caused by high flow rate of the air bubbles.

\section{Conclusions}

Industrial yeast biomass production is a well settled and simple process that has been improved along the years with the implementation of better process conception, design and control strategies. The present work focused on the process control improvement through a simple glucoselimited feeding strategy. The results shown herein are in good agreement with industrial reality and the spreadsheet simulator seams to be a useful tool in biomass production process operation and control.

\section{Acknowledgments}

To CAPES, Brazilian Coordination for the Improvement of Higher Education Personnel, for the fellowship awarded to the first author.

\section{References}

Aiba S (1971) Humphrey, A.E., Millis, N. F., Scale up In: Biochemical Engineering. University of Tokyo Press, Tokyo.

Akinyemi OP, Betiku E, BO Solomon (2005) Substrate Channelling and Energetics of Saccharomyces cerevisiae DSM 2155 Grown on Glucose in Fed-Batch Fermentation Process. Afr J Biotechnol 2:96-103.

Atkinson B, Mavituna F (1991) Biochemical Engineering and Biotechnology Handbook. Stockton Press, pp 120.

Bauer J, Luttik MAH, Flores CL, van Dijken JP, Pronk JT, Niederberger P (1999) By-product formation during exposure of respiring Saccharomyces cerevisiae cultures to excess glucose is not caused by a limited capacity of pyruvate carboxylase. FEMS Microbiol Lett 179:107-113.

Beudeker RF, van Dam HW, van der Plaat JB, Vellenga K (1990) Developments in baker's yeast production In: H. Verachtert and R. DeMot (eds.), Yeast biotechnology and biocatalysis. Marcel Dekker, New York, pp 103-146.

Burrows S (1979) Backer's Yeast In: Rose A. H. (ed), Microbial Biomass, vol.4, Academic Press, New York, pp 30-63.

Di Serio M, De Alteriis E, Parascandola P, Santacesaria E (2001) A general kinetic and mass transfer model to simulate the baker's yeast growth in bioreactors. Catal Today 66:437445 .
Di Serio M, Tesser R, Santacesaria E (2001) A kinetic and mass transfer model to simulate the growth of baker's yeast in industrial bioreactors. Chem Eng J 82:347-354.

Dynesen J, Smits HP, Olsson L, Nielsen J (1998) Carbon catabolite repression of invertase during batch cultivations of Saccharomyces cerevisiae: the role of glucose, fructose and mannose. Appl Microbiol Biotechnol 50:579-582.

EPA (1995). Yeast Production In: Compilation of Air Pollutant Emission Factors: AP-42, Fifth Edition, volume I, chapter 9.13.4. Available at: http://www.epa.gov/ttn/chief/ap42. Acessed June 20, 2011.

Fiecher A, Käppeli O, Meussdoerffer F (1987) Bath and Continuous Culture In: Rose, A. H. and Harrison, J.S. (Eds), The Yeast, Volume 2, $2^{\text {nd }}$ edition, Academic Press, New York, pp 99-129.

Frick O, Witmann C (2005) Characterization of the metabolic shift between oxidative and fermentative growth in Saccharomyces cerevisiae by comparative ${ }^{13} \mathrm{C}$ flux analysis. Microbial Cell Factories 4:30.

Halasz A, Lasztity R (1991) Use of yeast biomass in food production. CRC Press, Boca Raton, FL, 312 pp.

Hensing MCM, Rouwenhorst RJ, Heijnen JJ, van Dijken JP, Pronk JT (1995) Physiological and technological aspects of large-scale heterologous-protein production with yeasts. Anton van Lee 67:261-279.

van Dijken JP, Weusthuis RA, Pronk JT (1993) Kinetics of growth and sugar consumption by yeasts. Anton van Lee 63:343-352.

Jones KD, Kompala DS (1999) Cybernetic model of the growth dynamics of Saccharomyces cerevisiae in batch and continuous cultures, J Biotechnol 71:105-131.

Kantarcia N, Borakb F, Ulgen KO (2005) Bubble column reactors. Process Biochem 40:2263-2283.

Kappeli O (1986) Regulation of carbon metabolism in Saccharomyces cerevisiae and related yeasts. Adv Microb Physiol 28:181-209.

Lange HC, Heijnen JJ (2001) Statistical Reconciliation of the Elemental and Molecular Biomass Composition of Saccharomyces cerevisiae. Biotechnol. Bioeng. 75:334-344.

Rendez-Gil F, Sanz P, Prieto JA (1999) Engineering baker's yeast: room for improvement. Trends Biotechnol 17:237244.

Reyman G (1992) Modelling and control of fed-batch fermentation of bakers' yeast. Food Control 3:33-44.

Ringbom K, Rothberg A, Saxen B (1996) Model-based automation of baker's yeast production. J Biotechnol 51:73-82.

Rose AH (1979) History and Scientific Basis of Large-scale Production of Microbial Biomass In: Rose A. H. (Ed), Microbial Biomass, vol. 4, Academic Press, New York, pp 1-29.

Rose AH (1987) Responses to the Chemical Environment In: Rose, A. H and Harrison, J.S. (eds), The Yeast, Volume 2. $2^{\text {nd }}$ edition, Academic Press, New York, pp 5-40.

Soley A, Lecina M, Gámez X, Cairó JJ, Riu P, Rosell X, Bragós R, Gòdia F (2005) On-line monitoring of yeast cell growth by impedance spectroscopy. J Biotechnol 118:398-405.

Sonnleitner B, Käppeli O (1986) Growth of Saccharomyces cerevisiae is controlled by its limited respiratory capacity: for- 
mulation and verification of a hypothesis. Biotechnol Bioeng 28:927-937.

van Hoek P, Van Dijken J, Pronk J (1998) Effect of Specific Growth Rate on Fermentative Capacity of Baker's Yeast. Appl Environ Microbiol 64:4226-4233.
Verduyn C (1991) Physiology of yeasts in relation to biomass yields. Anton van Lee 60:325-53.

All the content of the journal, except where otherwise noted, is licensed under a Creative Commons License CC BY-NC. 